\title{
NYELVPOLITIKA HATÁROK NÉLKÜL
}

\section{LANGUAGE POLICY WITHOUT BORDERS}

\author{
Csernicskó István \\ PhD, egyetemi tanár, Pannon Egyetem, Veszprém, II. Rákóczi Ferenc Kárpátaljai Magyar Főiskola, Beregszász, Ukrajna \\ csernicsko.istvan@kmf.uz.ua
}

\begin{abstract}
ÖSSZEFOGLALÁS
A Szovjetunió széthullása és a szocializmust építő államokban lezajlott rendszerváltások után a Magyarországgal szomszédos államokban élő magyar közösségek megalapozottan bizakodhattak abban, hogy a társadalmi, politikai és gazdasági átalakulások után a kisebbségi és a nyelvi jogok területén is teljesen új korszak kezdődik, és a nyelvi jogok korlátozása hamarosan a múlt ködébe vész. Mára Magyarország és összes szomszédja egyaránt tagja az Európa Tanácsnak, illetve Ukrajna és Szerbia kivételével az Európai Uniónak is. A kisebbségi és a nyelvi jogok korlátozása időnként azonban máig feszültségeket okoz. Pedig az ilyen konfliktusok meghaladása iránti reményeket táplálták azok az európai egyezmények is, amelyeket épp az etnikai és nyelvi alapú konfliktusok megelőzése, a kisebbségi és nyelvi jogok kodifikálása céljából dolgoztak ki és javasoltak elfogadásra az 1990-es évek első felében. A Regionális vagy kisebbségi nyelvek európai kartája 1992-ben, a Keretegyezmény a nemzeti kisebbségek védelméről 1995-ben született az Európa Tanács égisze alatt, és a térség európai integrációt célul kitűző valamennyi állama - Magyarországot is beleértve - csatlakozott e két nemzetközi kisebbségvédelmi egyezményhez. A magyar nyelv használatának korlátozásából fakadó, az egész 20. századot végigkísérő nyelvi jogi problémák annak ellenére máig konfliktusok forrásai, hogy a magyar nyelv az összes Magyarországgal szomszédos államban a Karta védelme alá vont nyelvek közé tartozik, Magyarország pedig az összes, vele határos állam hivatalos nyelvét a Karta által védelmezett nyelvek közé sorolta. Írásunkban azt vizsgáljuk meg, hogy a két említett nemzetközi kisebbségvédelmi dokumentum általános elfogadottsága ellenére miért maradhattak fenn a 21. század elején is a nyelvpolitikai, nyelvi jogi problémák ebben a térségben. Bemutatjuk, hogy a nemzetközi jog elmarad számos állam nyelvi jogi gyakorlatától, és egyetlen nemzetközi dokumentum sem tartalmazza a nemzeti kisebbségek autonómiájához vagy a kisebbségi nyelvek hivatalos státuszának elismeréséhez való jogot. Ehelyett a nemzetközi jog csupán homályos minimumsztenderdeket sorol fel, és azokat is csupán ajánlások formájában.
\end{abstract}

\section{ABSTRACT}

After the disintegration of the Soviet Union and the regime changes in the Central European states, Hungarian communities living in the neighbouring countries of Hungary hopefully anticipated that after a social, political and economic transformation a new era would start in minority and linguistic rights. At the beginning of the 1990s, there was a chance that the restric- 
tion of language rights would cease. Hungary and its neighbours now are all members of the European Council and the European Union (with the exception of Ukraine and Serbia). However, the restriction of minority and linguistic rights sometimes causes tensions still despite European conventions, which were developed and recommended for the prevention of ethnic and linguistic conflicts, the codification of minority and linguistic rights and their adoption in the first half of the 1990s, gave hope for overcoming such conflicts. In 1992 European Charter for Regional or Minority Languages, in 1995 the Framework Convention for the Protection of National Minorities was born under the support of the Council of Europe. All states in the Central European region, including Hungary, have joined these two international minority protection conventions. However, the legal issues arising from the limitation of the use of the Hungarian language throughout the $20^{\text {th }}$ century are still sources of conflict, in spite of the Hungarian language belonging to the languages protected by the Charter in all the states neighbouring Hungary, and that Hungary has classified the official language of all its neighbouring states as languages protected by the Charter. In this study, we examine why language policy and linguistic problems could persist in this region in the early $21^{\text {st }}$ century, despite the general acceptance of the two international minority protection documents mentioned above. The analysis shows that international law is lagging behind the linguistic practice of many states. It is pointed out that no international document contains the right to the recognition of autonomy of national minorities or the recognition of the official status of minority languages. Instead, international law lists only vague minimum standards, and only in the form of recommendations.

Kulcsszavak: nyelvpolitika, nyelvi emberi jogok, Regionális vagy kisebbségi nyelvek európai kartája, Keretegyezmény a nemzeti kisebbségek védelméről, anyanyelvi oktatás

Keywords: language policy, linguistic human rights, European Charter for Regional or Minority Languages, Framework Convention for the Protection of National Minorities, mother-tongue-medium education

\section{BEVEZETŐ}

A Szovjetunió széthullása és a szocializmust építő államokban lezajlott rendszerváltások után a Magyarországgal szomszédos államokban élő magyar közösségek megalapozottan bizakodhattak abban, hogy a társadalmi, politikai és gazdasági átalakulások után a kisebbségi és a nyelvi jogok területén is teljesen új korszak kezdődik, és a nyelvi jogok korlátozása hamarosan a múlt ködébe vész. Mára Magyarország és szomszédai egyaránt tagjai az Európa Tanácsnak (ET), illetve Ukrajna és Szerbia kivételével az Európai Uniónak is. A kisebbségi és a nyelvi jogok korlátozása időnként azonban máig feszültségeket okoz. Pedig az ilyen konfliktusok meghaladása iránti reményeket táplálták azok az európai egyezmények is, amelyeket épp az etnikai és nyelvi alapú konfliktusok megelözése, a kisebbségi és nyelvi jogok kodifikálása céljából dolgoztak ki és javasoltak elfogadásra az 1990-es évek első felében. A Regionális vagy kisebbségi nyelvek európai kartája (a továbbiakban: Karta; URL1) 1992-ben, a Keretegyezmény a nemzeti kisebb- 
ségek védelméről (a későbbiekben: Keretegyezmény; URL2) 1995-ben született az Európa Tanács égisze alatt, és a térség - európai integrációt célul kitúző - valamennyi állama - Magyarországot is beleértve - csatlakozott e két nemzetközi kisebbségvédelmi egyezményhez (1. táblázat).

1. táblázat. A Karta és a Keretegyezmény (ratifikációt követő) hatályba lépésének éve Magyarországon és a szomszédos államokban

\begin{tabular}{|l|c|c|}
\hline & Karta (URL3) & Keretegyezmény (URL4) \\
\hline Magyarország & 1998 & 1995 \\
Szlovákia & 2002 & 1995 \\
Ukrajna & 2006 & 1998 \\
Románia & 2008 & 1995 \\
Szerbia & 2006 & 2001 \\
Horvátország & 1998 & 1997 \\
Szlovénia & 2001 & 1998 \\
Ausztria & 2001 & 1998 \\
\hline
\end{tabular}

2. táblázat. A Regionális vagy kisebbségi nyelvek európai kartája védelme alá vont nyelvek Magyarországon és a szomszédos államokban (URL5)

\begin{tabular}{|c|c|c|c|c|c|c|c|c|}
\hline & 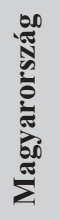 & $\begin{array}{l}\frac{\pi}{\sqrt{n}} \\
\frac{\pi}{\pi} \\
\frac{0}{N} \\
\text { N }\end{array}$ & 芯 & 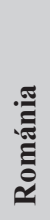 & 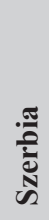 & 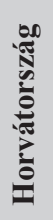 & 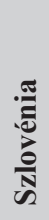 & \\
\hline magyar & & + & + & + & + & + & + & + \\
\hline szlovák & + & & + & + & + & + & & + \\
\hline ukrán & + & + & & + & + & + & & \\
\hline román & + & & + & & + & & & \\
\hline szerb & + & & & + & & + & + & \\
\hline horvát & + & + & & + & + & & + & + \\
\hline szlovén & + & & & & & + & & + \\
\hline német & + & + & + & + & + & + & + & \\
\hline
\end{tabular}


A magyar nyelv használatának korlátozásából fakadó, az egész 20. századot végigkísérő nyelvi jogi problémák - amint arról például A magyar nyelv a Kárpát-medencében a XX. század végén címü könyvsorozat kötetei vagy éppen a Termini Kutatóhálózat munkatársainak elemzései (lásd például Csernicskó-Szabómihály, 2010; Csernicskó et al., 2010; Szabómihály, 2017) is rámutatnak - annak ellenére máig konfliktusok forrásai, hogy a magyar nyelv az összes Magyarországgal szomszédos államban a Karta védelme alá vont nyelvek közé tartozik, Magyarország pedig az összes, vele határos állam hivatalos nyelvét a Karta által védelmezett nyelvek közé sorolta (2. táblázat).

Írásunkban azt vizsgáljuk meg röviden, hogy a két említett nemzetközi kisebbségvédelmi dokumentum általános elfogadottsága ellenére miért maradhattak fenn a 21. század elején is a nyelvpolitikai, nyelvi jogi problémák ebben a térségben.

\section{MIRE KÖTELEZNEK A NEMZETKÖZI EGYEZMÉNYEK?}

Az említett két európai kisebbségvédelmi dokumentum céljairól, tartalmáról számos elemzés olvasható magyarul is (lásd például Fiala-Butora, 2017; Kardos, 2017; Szalayné Sándor, 2017). Hogy ne általában szóljunk arról, milyen kötelezettségeket ró a Kartát és a Keretegyezményt ratifikáló államokra a nyelvi jogok területén e két dokumentum, az alábbiakban azt vizsgáljuk meg röviden, hogy egy konkrét területen: a kisebbségek anyanyelvi oktatása terén mit kell teljesíteniük a részes államoknak.

Közvetlenül az oktatás témakörét a Keretegyezmény 12-14. cikke, illetve a Karta 8. cikke érinti. A Keretegyezmény 12. cikkének három bekezdése közül az első azt irányozza elő, hogy az oktatást úgy célszerü megszervezni, hogy a többségiek és a kisebbségiek megismerjék egymás kultúráját, nyelvét és hagyományait. A második bekezdés a pedagógusok képzését és a tankönyvellátást említi. A harmadikban az oktatási esélyegyenlöség mellett teszi le a voksot a nemzetközi dokumentum. A 13. cikk két bekezdése a kisebbségek magán oktatási intézmények alapítására vonatkozó jogát rögzíti, megjegyezve, hogy ez a jog semmilyen anyagi kötelezettséget nem ró az államokra.

A 14. cikk mond a legtöbbet a kisebbségi oktatásról. A cikk első bekezdése arra kötelezi az egyezményt ratifikáló államokat, hogy biztosítsák minden kisebbségi számára saját nyelvük megtanulásának jogát. A következő bekezdés megfogalmazza, hogy a kisebbségeknek joguk van „kisebbségi nyelvüket megtanulni vagy ezen a nyelven tanulni”. Ezt a jogot azonban számos, az idézett bekezdésben szövegszerüen rögzített, jogilag értelmezhetetlen tényezö teszi relatívvá, a gyakorlatban számonkérhetetlenné. A 14. cikk 2. pontja ugyanis a következöképpen van megfogalmazva: 
„Nemzeti kisebbségek által hagyományosan és jelentős számban lakott területeken, megfelelö igény esetén, a Felek törekednek - lehetőségeik szerint és oktatási rendszerük keretein belül - annak biztosítására, hogy a nemzeti kisebbségekhez tartozó személyeknek megfelelö lehetöségük legyen kisebbségi nyelvüket megtanulni vagy ezen a nyelven tanulni."

Sehol sem derül ki azonban, mit jelent az, hogy „hagyományosan és jelentős számban" kell a kisebbségeknek az adott államban élniük a nevezett jog érvényesítéséhez. Az sem világos, hogyan kell értelmezni a „megfelelő igényt”. Akkor sem jutunk közelebb az anyanyelv megtanulásához vagy az anyanyelven folyó oktatáshoz füződő jog gyakorlati alkalmazásához, ha esetleg az állami végrehajtó hatalom úgy találja, hogy egy adott nemzeti kisebbség képviselöi „hagyományosan és jelentős számban" élnek az ország területén, és az általuk kifejezett igényt is megfelelőnek ítélte. Ez esetben is csak arra vállal kötelezettséget az állam, hogy „lehetőségeik szerint és oktatási rendszerük keretein belül” „törekednek” annak biztosítására, hogy a kisebbségeknek „megfelelő lehetőségük legyen” a Keretegyezmény e pontjában megfogalmazott jog érvényesítésére. Az azonban nem derül ki, hogy ez milyen kötelezettséget ró az államra a „megfelelö lehetőség” biztosítása területén. Mindezt tetézi a 14. cikk harmadik bekezdése, amely kijelenti, hogy az előző bekezdést ,úgy kell végrehajtani, hogy az ne veszélyeztesse a hivatalos nyelv tanulását vagy ezen a nyelven való tanítást”.

A Kartát ratifikáló államok - bizonyos megkötésekkel - à la carte rendszerben válogathatnak a dokumentumban kínált rendelkezések közül. A választás egyik része az, hogy az állam választhat, mely nyelvekre terjeszti ki a Karta hatályát. A másik része pedig az, hogy az államok - a dokumentum I. rész 2. cikkében foglalt elöírásokat figyelembe véve - válogathatnak a Karta rendelkezései közül úgy, hogy a II. részt mindenképpen alkalmazzák, a III. rész rendelkezései közül pedig „,legkevesebb harmincöt bekezdést vagy pontot” alkalmaznak, mégpedig „legalább hármat-hármat a 8. és 12. cikkből és egyet-egyet a 9., 10., 11. és 13. cikkből” (Kardos, 2017).

Azt, hogy az oktatás területén milyen lehetőségek közül választhatnak az államok, a 8. cikk 1. pontjának egy részletét áttekintve mutatjuk be. A Karta 8 . cikkének 1. pontja az óvodától az egyetemig és a felnőttoktatásig az alábbi lehetőségeket kínálja:

„1. Az oktatásügyet illetően a Felek azokon a területeken, ahol ezeket a nyelveket használják, e nyelvek mindegyike helyzetének megfelelően, és anélkül, hogy az állam hivatalos nyelvének/nyelveinek oktatása hátrányt szenvedne, vállalják, hogy [...]

b. i. elérhetővé teszik az általános iskolai oktatást az érintett regionális vagy kisebbségi nyelveken, vagy

ii. elérhetővé teszik az általános iskola lényegi részét az érintett regionális vagy kisebbségi nyelveken, vagy 
iii. biztosítják, hogy az érintett regionális vagy kisebbségi nyelvek oktatása az általános iskolai tanrend integráns részét képezze, vagy

iv. a fenti i.-iii. szerinti intézkedések valamelyikét legalább azokra a tanulókra alkalmazzák, akiknek családja ezt kívánja, és létszáma elegendőnek minősül [...]”.

Egyáltalán nem mindegy, hogy melyik opciót választja egy adott állam: miközben az i. azt jelenti, hogy a kisebbségek anyanyelvükön tanulhatnak, az iii. már csak azt, hogy nyelvük tantárgyként van jelen az oktatási folyamatban. Azt, hogy a Magyarországgal szomszédos államok milyen kötelezettségeket vállaltak a magyar nyelv vonatkozásában az oktatás területén, a 3. táblázatban foglaltuk össze.

3. táblázat. A Magyarországgal szomszédos államoknak a Karta 8., az oktatásról szóló cikke területén a magyar nyelvvel kapcsolatban tett vállalásai (URL6)

\begin{tabular}{|c|c|c|c|c|c|c|c|}
\hline & 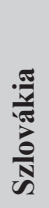 & 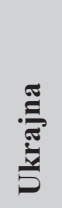 & 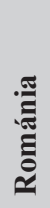 & & 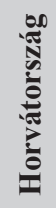 & 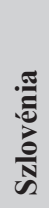 & 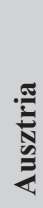 \\
\hline \multicolumn{8}{|l|}{ 1. pont } \\
\hline a) iskola-előkészítő oktatás & i. & iii. & i. & iii. & iii. & ii. & ii. \\
\hline b) általános iskolai oktatás & i. & iv. & i. & iv. & iv. & ii. & ii. \\
\hline c) középiskolai oktatás & i. & iv. & i. & iv. & iv. & ii. & iii. \\
\hline d) szakközépiskola és szakmunkásképzés & i. & iv. & i. & iv. & iv. & ii. & iv. \\
\hline e) felsőoktatás & i. & iii. & i. & iii. & iii. & iii. & iii. \\
\hline f) felnőttoktatás és továbbképzés & i. & iii. & i. & iii. & iii. & iii. & iii. \\
\hline g) a kisebbség történelmének, kultúrájának oktatása & + & + & + & + & + & + & + \\
\hline $\begin{array}{l}\text { h) kisebbségi nyelven oktató pedagógusok } \\
\text { továbbképzése }\end{array}$ & + & + & + & & + & + & + \\
\hline $\begin{array}{l}\text { i) a kisebbségi nyelvű oktatás felügyelö és tanácsadó } \\
\text { szervének létrehozása }\end{array}$ & + & + & + & & & + & + \\
\hline $\begin{array}{l}\text { 2. pont: igény szerint a településterületen kívül is } \\
\text { megszervezik a kisebbségi nyelven az oktatást }\end{array}$ & & + & + & & & + & + \\
\hline
\end{tabular}


Láthatjuk, hogy az egyes államok különböző kötelezettségeket vállaltak. Szembetűnő, hogy Szlovákia és Románia - ahol az óvodától az egyetemig terjedő magyar nyelvű oktatási intézményrendszer működik - a legmagasabb szintű vállalásokat tette. Ukrajna és Szerbia ezzel szemben - annak ellenére, hogy e két ország magyarsága is fejlett anyanyelvủ oktatási hálózattal rendelkezik - meglehetősen alacsony szintü kötelezettségeket vállalt.

A két nemzetközi dokumentum alkalmazásáról az államok rendszeres időközönként jelentést nyújtanak be az ET megfelelő testületeihez. A Keretegyezmény vonatkozásában a Tanácsadó Bizottság (URL7), a Karta esetében pedig a Szakértői Bizottság (URL8) rendszeres időközönként - figyelembe véve az országjelentéseket - szintén jelentéseket állít össze arról, hogyan alkalmazzák az egyes államok az említett nemzetközi dokumentumokat saját területükön. Ezeknek a jelentéseknek az áttekintése és elemzése azért lényeges, mert a jelentések elvileg ,fontos iránymutatóul, egyfajta objektív tükörként szolgálnak a nemzetközi és hazai fórumokon a kisebbségi jogok helyzetével kapcsolatban: a kisebbségi jogok mércéjéül sokszor nem maga az egyezmények szövege, hanem annak a bizottságok által elfogadott értelmezése szolgál" (Fiala-Butora, 2017, 57.).

A Tanácsadó Bizottság és a Szakértői Bizottság legutóbbi jelentéseit megvizsgálva Nagy Noémi (2017; 2018), Fiala-Butora János (2017) és Tóth Norbert (2017) arra a következtetésre jutottak, hogy a Magyarországgal szomszédos államok csaknem mindegyike kapott kritikákat amiatt, hogy nem teljesítette az oktatás területén tett vállalásait.

A Karta implementációjáról a Szakértői Bizottság által készített legfrissebb, 2017-ben és 2018-ban kiadott jelentések 2. fejezete már táblázatos formába foglalja, hogyan teljesítik az egyes államok a Karta ratifikációs törvényében tett vállalásaikat az egyes, a dokumentum hatálya alá vont nyelvek vonatkozásában. Az egyes országokról kiadott jelentések elemzése lehetőséget kínál számunkra, hogy mi is konkrétan megvizsgáljuk, hogy a Magyarországgal szomszédos országok milyen mértékben teljesítették a magyar nyelv vonatkozásában saját vállalásaikat az oktatás területén. A horvátországi, szlovákiai és szlovéniai helyzetről nem készült még az új szempontok szerint kiadott jelentés, így most ezeket az államokat kihagyjuk a következő összefoglalásból. Azt azonban meg tudjuk vizsgálni, hogyan látta a Szakértői Testület az oktatási jogok biztosítását Ukrajnában, Romániában, Szerbiában és Ausztriában.

A Szakértői Bizottság jelentései alapján összeállított 4. táblázat egyes celláiban szereplő számok a következő kategóriákat fedik (a hivatalos jelentésben szereplő szempontok szerint):

4. Megvalósult: A politikák, a jogszabályok és a gyakorlat megfelel a Karta követelményeinek. 
3. Részben teljesült: A politikák és a jogszabályok teljes egészében vagy részben megfelelnek a Karta rendelkezéseinek, de a kötelezettségvállalást csak részben hajtják végre a gyakorlatban.

2. Formálisan teljesült: A szakpolitikák és a jogszabályok összhangban vannak a Kartával, de a gyakorlatban nincsenek végrehajtva a vállalások.

1. Nem teljesült: A kötelezettség teljesítése érdekében a politika, a jog és a gyakorlat területén nem tettek lépéseket a hatóságok, vagy a Szakértői Bizottság több monitoring cikluson át sem kapott semmilyen információt azok végrehajtásáról.

0. Nincs következtetés: A Szakértői Bizottság nem tudja megállapítani a kötelezettségvállalás teljesítését, mivel a hatóságok nem nyújtottak ehhez elegendő információt.

(Sötétszürkével jelöltük azt a cellát, amely rész alkalmazását az adott állam nem vállalta.)

4. táblázat. Mennyiben felelnek meg az egyes államok

a Karta 8. cikke (oktatás) kapcsán tett saját vállalásaiknak a magyar nyelv vonatkozásában?

A Szakértői Bizottság hivatalos értékelése alapján (URL9)

\begin{tabular}{|c|c|c|c|c|}
\hline & & 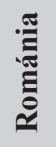 & 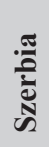 & 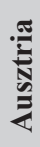 \\
\hline \multicolumn{5}{|l|}{ 1. pont } \\
\hline a) iskola-előkészítő oktatás & 4 & 4 & 4 & 4 \\
\hline b) általános iskolai oktatás & 4 & 4 & 4 & 4 \\
\hline c) középiskolai oktatás & 4 & 4 & 4 & 4 \\
\hline d) szakközépiskolai és szakmunkásképzés & 1 & 3 & 4 & 4 \\
\hline e) felsőoktatás & 4 & 4 & 4 & 4 \\
\hline f) felnőttoktatás és továbbképzés & 4 & 3 & 3 & 4 \\
\hline g) a kisebbség történelmének, kultúrájának oktatása & 3 & 3 & 3 & 1 \\
\hline h) kisebbségi nyelven oktató pedagógusok továbbképzése & 4 & 3 & - & 4 \\
\hline $\begin{array}{l}\text { i) a kisebbségi nyelvü oktatás felügyelő és tanácsadó szervének } \\
\text { létrehozása }\end{array}$ & 1 & 0 & - & 3 \\
\hline $\begin{array}{l}\text { 2. pont: igény szerint a településterületen kívül is megszervezik a } \\
\text { kisebbségi nyelven az oktatást }\end{array}$ & 1 & 4 & - & 4 \\
\hline
\end{tabular}


Amint a 4. táblázatban látjuk, a 2017-2018-as jelentések szerint alapjában véve mind a négy állam teljesítette a magyar nyelv kapcsán az oktatás területén vállalt kötelezettségeit, ám egyetlen államnál sincs mindegyik pont mellett maximális pontszám. S ha ehhez hozzátesszük, hogy az ukrajnai jelentés a 2017. október 5-én elfogadott új oktatási kerettörvény, illetve a 2019. április 25-én megszavazott új államnyelvi törvény hatályba lépése elött készült, akkor az is világossá válik, hogy miért van szükség a Keretegyezmény és a Karta alkalmazásának folyamatos monitoringjára.

\section{NYELV ÉS IDEOLÓGIA}

Felmerül a kérdés: mi lehet az oka annak, hogy az államok nem teljesítik (teljes mértékben) saját vállalásaikat? Ennek hátterében nyelvi ideológiák állnak.

A nyelvi ideológiák olyan eszmék, elképzelések, melyek a nyelvvel (a nyelvi rendszerrel, a nyelvhasználattal, a nyelvek egymáshoz viszonyított helyzetével, a nyelven belüli változatokkal, a beszélőközösségekkel) kapcsolatos tények, vélemények, cselekedetek magyarázatára szolgálnak, illetve melyek a nyelv(ek)re/ nyelvhasználatra/nyelvváltozatokra és beszélöikre irányuló cselekedetek hátterében állnak, befolyásolják a nyelvpolitikát, oktatáspolitikát, s valójában gazdasági, politikai és kulturális értékek, érdekek és ideológiák húzódnak meg mögöttük; a nyelvi ideológiák a nyelvet a társadalmi csoportok értékein és érdekein keresztül jelenítik meg, befolyásolják a nyelv(ek)ről, nyelvváltozatokról és beszélöikről alkotott társadalmi képet (Lanstyák, 2009).

A nyelvpolitika mögött nyelvi ideológiák állnak. A nyelvek státuszát, használati körét, de a jogszabályokban rögzített jogok gyakorlati megvalósítását ugyanis az adott állam nyelvpolitikája határozza meg. A nyelvpolitika Bernard Spolsky $(2009,4$.) megfogalmazása szerint „egy személy vagy valamely csoport kifejezett és nyilvánvaló erőfeszítése [...] a résztvevők [nyelvi] gyakorlatának vagy meggyőződésének módosítására".

A nyelvpolitika egyik céljának gyakran a nyelvi konfliktusok elkerülését vagy kezelését, illetve a társadalmi jólét növelését szokták tekinteni. Joseph G. Turi $(1994,11$.) például úgy véli, hogy a nyelvi jogi szabályozások alapvető célja a nyelvek közötti konfliktusokból és egyenlőtlenségekből eredő nyelvi problémák megoldása, az érintett nyelvek státuszának megállapítása és használati körének meghatározása révén. François Grin $(2003,30$.) szerint pedig a nyelvpolitika olyan szisztematikus, racionális és elméletileg megalapozott társadalmi szintủ erőfeszítés a nyelvi környezet megváltoztatására, amely a jólét növelését célozza.

Ezek szép célok. Valójában azonban ennél árnyaltabb a kép. Klaus Bochmann (1999, 28-31.) definíciója szerint a nyelvpolitika „egy társadalmi közösség kom- 
munikációs gyakorlatának szabályozása egy olyan csoport által, amely nyelvi és kulturális hegemóniával rendelkezik, illetve ennek elérésére törekszik. [...] A nyelvpolitika, mint a politika minden más fajtája, [...] bizonyos csoportok/rétegek/osztályok érdekeinek van alárendelve". James W. Tollefson (1991) szerint pedig a nyelvpolitika egy mechanizmus, amely úgy helyezi társadalmi struktúrába a nyelvet, hogy az adott társadalomban a nyelv révén válik meghatározottá, ki fér hozzá a politikai hatalomhoz és a gazdasági erőforrásokhoz.

A nyelvpolitika tehát hatékony eszközként használható a társadalmi javak és a politikai tőke egyenlőtlen elosztásának eléréséhez, illetve megideologizálásához, és gyakran éppen erre használják. A nyelvpolitika ebben az elméleti keretben a hatalom megszerzésének és megtartásának, a társadalmi egyenlőtlenség kialakításának és újratermelésének egyik mechanizmusa. A nyelvpolitika hatáskörébe vont kérdések gyakran a hatalomért folytatott harc álcázására szolgálnak (RoterBusch, 2018, 156.). A törvényekben, egyezményekben rögzített jogok gyakran épp a hatalmi praktikák révén válnak üres szólamokká.

Rogers Brubaker és szerzőtársai (2011, 36-37.) szerint a nemzetállamot építő elitek az általuk ellenörzött területre ,úgy tekintenek, mint olyan edényre, amely nemzeti nyelvvel és kultúrával »tölthető« és töltendő fel", és a nyelvpolitikát a nemzetiesítés hatékony eszközeként használják. Amikor a többségi nemzet tagjai saját nyelvüket eröltetik a kisebbségekre, s amikor mindezt arra hivatkozva teszik, hogy a kisebbségiek jobban járnak, ha magas szinten megtanulják ezt a nyelvet, és saját nyelvük helyett inkább azt használják (legalábbis a nyilvános szituációkban), akkor arról tesznek tanúbizonyságot, hogy a domináns nyelvi csoport számára természetes az államnyelv és az ezt hordozó többségi etnikum jogilag is legitimált privilegizált helyzete. Brubaker és szerzőtársai $(2011,261$. szerint „Ez egyenesen következik abból a nacionalista alapállásból, amelyet a domináns »államalkotó« nemzetekkel azonosuló egyének széles körben vallanak, nevezetesen hogy a nemzetállam lényegénél fogva egy adott nemzeté és azért a nemzetért van".

A domináns csoport tagjai számára azért is természetesnek tünhet ez a fajta szemlélet, mert országuk neve rendszerint magában foglalja a többségi etnikumnak és nyelvének nevét, és ez mintegy implikálja számukra, hogy ez a nemzet az államiság birtokosa, ők vannak otthon. Innen csupán egy lépés az a szemlélet, mely szerint saját államukban csak a domináns csoport nyelve lehet az egyetlen államnyelv és hivatalos nyelv. Így válik a nyelv a kommunikáció és az identitásjelzés eszközéből politikai és nemzeti szimbólummá. „Ez az elgondolás - ami olyan magától értetődőnek tűnik, hogy nem is igényel különösebb átgondolást vagy indoklást - a hétköznapi nyelvi ideológia egyik központi eleme" (Brubaker et al., 2011, 261.).

A nemzetállamot építő politikai elitek a nyelvpolitikát elsősorban nem a társadalmi egyenlőtlenség felszámolására, hanem a nemzetállami ideológia eszköze- 
ként használják. Ezért van az, hogy számos európai állam nem is csatlakozott az említett nemzetközi kisebbségvédelmi egyezményekhez (5. táblázat), és ez nem növeli azok erejét, presztízsét.

5. táblázat. Az Európa Tanács 47 tagállamának viszonya az európai kisebbségvédelem két alapdokumentumához

\begin{tabular}{|l|c|c|}
\hline & Karta & Keretegyezmény \\
\hline Aláírta és ratifikálta & 25 & 41 \\
Aláírta, de nem ratifikálta & 8 & 4 \\
Alá sem írta & 14 & 2 \\
\hline
\end{tabular}

Azok az államok pedig, amelyek vállalták a Karta és a Keretegyezmény alkalmazását, szinte alig vannak korlátozva asszimilációs nyelvpolitikájukban, hiszen a nyelvi kisebbségek védelmét ezek a nemzetközi dokumentumok csak nagyon enyhén védelmezik (Skutnabb-Kangas, 2000; Leung, 2018).

Térségünk vizsgált államairól is írva Aneta Pavlenko $(2011,44$.$) megállapít-$ ja: „A kezdeti nyugati próbálkozások, hogy megtanítsák az újonnan feltörekvő országoknak, hogy a »jó liberális demokráciák« miként döntenek a nyelvpolitikai dilemmákban, gyorsan ahhoz a felismeréshez vezettek, hogy a Nyugat nagyon messze van az etnolingvisztikai kérdések »megoldásától«, és hogy valójában nincs a nyelvi jogoknak normatív elmélete". Will Kymlicka $(2015,8$.) szerint a nemzetközi jog elmarad számos állam nyelvi jogi gyakorlatától, és bár több államban ez létező jog, egyetlen nemzetközi dokumentum sem tartalmazza a nemzeti kisebbségek autonómiájához vagy a kisebbségi nyelvek hivatalos státuszának elismeréséhez való jogot. Ehelyett a nemzetközi jog csupán homályos minimumsztenderdeket sorol fel, és azokat is csupán ajánlások formájában (Kymlicka, 2015, 9.).

\section{IRODALOM}

Bochmann, K. (1999): A nyelvpolitika elmélete, módszerei és elemzése. In: Szépe Gy. - Derényi A. (szerk.): Nyelv, hatalom, egyenlöség. Nyelvpolitikai irások. Budapest: Corvina Kiadó, 25-69.

Brubaker, R. - Fleischmidt, M. - Fox, J. et al. (2011): Nacionalista politika és hétköznapi etnicitás egy erdélyi városban. Budapest: L'Harmattan Kiadó, http://mek.oszk.hu/17300/17346/17346. pdf

Csernicskó I. - Péntek J. - Szabómihály G. (2010): A határon túli magyar nyelvváltozatok a többségi nyelvpolitikák rendszerében: Románia és Ukrajna példája. Regio, 21, 3, 3-36. http://real. mtak.hu/23329/ 
Csernicskó I. - Szabómihály G. (2010): Hátrányból előnyt: a magyar nyelvpolitika és nyelvtervezés kihívásairól. In: Bitskey B. (szerk.): Határon túli magyarság a 21. században: konferenciasorozat a Sándor-palotában 2006-2008. Budapest: Köztársasági Elnöki Hivatal, 167-198. http://real.mtak.hu/25277/

Fiala-Butora J. (2017): A Kisebbségvédelmi keretegyezmény és a Nyelvi Charta végrehajtása - egységes standard vagy szétfejlődés? Kisebbségi Szemle, II, 3, 57-69.

Grin, F. (2003): Language Policy Evaluation and the European Charter for Regional or Minority Languages. Basingstoke: Palgrave Macmillan DOI: 10.1057/9780230502666, https://www. researchgate.net/publication/317847640_Language_Policy_Evaluation_and_the_European_ Charter_for_Regional_or_Minority_Languages

Kardos G. (2017): Mérlegen a Nyelvi Charta. Kisebbségi Szemle, II, 3, 33-41. https://bgazrt.hu/ wp-content/uploads/NPKI folyoiratok/kisebbsegi szemle/2017 03/ksz201703 5.Kardos.pdf

Kymlicka, W. (2015): Multiculturalism and Minority Rights: West and East. Journal on Ethnopolitics and Minority Issues in Europe, 14, 4, 4-25. https:/www.ecmi.de/fileadmin/redakteure/ publications/JEMIE_Datens\%C3\%A4tze/Jemie_datens\%C3\%A4tze_2015/Kymlicka.pdf

Lanstyák I. (2009): Nyelvi ideológiák és filozófiák. Fórum Társadalomtudományi Szemle, 1, $27-$ 44. http://dragon.unideb.hu/ tkis/li_nyviideolesfil.pdf

Leung, J. (2018): Language Rights. In: Visconti, J. (ed.): The Handbook of Communication in the Legal Sphere. Berlin-Boston: De Gruyter, 54-82. DOI: 10.1515/9781614514664-004, https:// www.researchgate.net/publication/331180196_Language_rights

Nagy N. (2017): Language Rights of Minorities in the Areas of Education, the Administration of Justice and Public Administration: European Developments in 2017. European Yearbook of Minority Issues, 16, 63-97.

Nagy N. (2018): A nemzeti kisebbségek nyelvi jogainak aktuális helyzete az Európa Tanács intézményei tevékenységének tükrében. Pro Minoritate, 2, 47-70. https://prominoritate.hu/wp-content/uploads/2019/05/ProMino-1802-04-Nagy-1.pdf

Pavlenko, A. (2011): Language Rights Versus Speakers' Rights: On the Applicability of Western Language Rights Approaches in Eastern European Contexts. Language Policy, 10, 37-58. DOI: 10.1007/s10993-011-9194-7, https://bit.ly/384eRS6

Roter, P. - Busch, B. (2018): Language Rights in the Work of the Advisory Committee. In: Ulasiuk, I. - Hadîrcă, L. - Romans, W. (eds.): Language Policy and Conflict Prevention. Leiden-Boston: Brill Nijhoff, 155-181.

Skutnabb-Kangas, T. (2000): Linguistic Genocide in Education - Or Worldwide Diversity and Human Rights? Mahwah, NJ: Lawrence Erlbaum Associates

Spolsky, B. (2009): Language Management. New York: Cambridge University Press

Szabómihály G. (2017): A magyar nyelv használata a közigazgatásban a Magyarországgal szomszédos országokban. In: Tolcsvai Nagy G. (szerk.): A magyar nyelv jelene és jövöje. Budapest: Gondolat Kiadó, 299-320. http://real.mtak.hu/74985/1/Tolcsvai_Magyarnyelv_javitott_nyomdanak.pdf

Szalayné Sándor E. (2017): A kisebbségvédelmi keretegyezmény húsz év után - tapasztalatok a negyedik monitoring ciklus végén. Kisebbségi Szemle, II, 3, 43-56. https://bgazrt.hu/wp-content/uploads/NPKI_folyoiratok/kisebbsegi_szemle/2017_03/ksz201703_6.Szalayne.pdf

Tollefson, J. W. (1991): Planning Language, Planning Inequality. Language Policy in the Community. London-New York: Longman

Tóth N. (2017): Fából vaskarika, avagy reflexiók a Kisebbségvédelmi keretegyezmény Tanácsadó Bizottságának ún. 4. tematikus kommentárjára vonatkozóan. Kisebbségi Szemle, II, 3, 71-88. https://bgazrt.hu/wp-content/uploads/NPKI_folyoiratok/kisebbsegi_szemle/2017_03/ ksz201703_8.Toth.pdf 
Turi, J. G. (1994): Typology of Language Legislation. In: Skutnabb-Kangas, T. - Phillipson, R. (eds.): Linguistic Human Rights: Overcoming Linguistic Discrimination. Berlin: Mouton, 111119. DOI:10.1515/9783110866391.111, https://www.researchgate.net/publication/333190957_Typology_of_language_legislation

URL1: European Charter for Regional or Minority Languages. https://www.coe.int/en/web/conventions/full-list///conventions/rms/0900001680695175

URL2: Framework Convention for the Protection of National Minorities and Explanatory Report. https://rm.coe.int/CoERMPublicCommonSearchServices/DisplayDCTMContent?document$\mathrm{Id}=09000016800 \mathrm{c} 10 \mathrm{cf}$

URL3: Opening for Signature and Entry into Force of the European Charter for Regional or Minority Languages. https://archive.is/PdMz

URL4: State Parties to the Framework Convention for the Protection of National Minorities. https://www.coe.int/en/web/minorities/etats-partie

URL5: States Parties to the European Charter for Regional or Minority Languages and Their Regional or Minority Languages. https://rm.coe.int/states-parties-to-the-european-charter-for-regional-or-minority-langua/168077098c

URL6: Reservations and Declarations for Treaty No.148 - European Charter for Regional or Minority Languages. https:/www.coe.int/en/web/conventions/full-list/-/conventions/treaty/148/ declarations?p_auth=adpW1NPl

URL7: Advisory Committee on the Framework Convention for the Protection of National Minorities. https://www.coe.int/en/web/minorities/advisory-committee

URL8: Committee of Experts of the European Charter for Regional or Minority Languages. https://www.coe.int/en/web/european-charter-regional-or-minority-languages/committeeof-experts

URL9: Council of Europe: Reports and Recommendations. https:/www.coe.int/en/web/europeancharter-regional-or-minority-languages/reports-and-recommendations 